\title{
DA ACUMULAÇÃO PRIMITIVA AOS REGIMES DE DESAPROPRIAÇÃO
}

Tradução de Markus Hediger

Este ensaio é um resumo de um livro ainda inédito sobre a desapropriação de terras na Índia, cuja finalidade é promover uma teoria da relação entre a desapropriação de terra e o capitalismo. Essa relação tem sido historicamente ignorada pela sociologia e permanece inadequadamente teorizada em estudos empíricos recentes sobre a "tomada de terras". Os marxistas, por sua vez, sempre tiveram uma teoria sobre a desapropriação, fundamentada na análise de Marx da "acumulação primitiva". Sustento, porém, que a "acumulação primitiva" é um conceito inadequado e enganoso para compreender as contínuas desapropriações de terras no capitalismo avançado. A reformulação de Harvey do conceito como "acumulação por desapropriação" fornece o ponto de partida necessário, mas é comprometida pelo economicismo e funcionalismo e precisa ser substancialmente reconstruída. Para superar essas lacunas na teoria de Harvey, defenderei o conceito dos "regimes de desapropriação" como uma estrutura mais esclarecedora e politicamente mais efetiva para o estudo comparativo da desapropriação.

\section{A DESAPROPRIAÇÃO NA SOCIOLOGIA}

Ainda não existe uma sociologia da desapropriação. Apesar de já ter emergido nas periferias de várias subdisciplinas sociológicas, a questão da relação sociológica específica da desapropriação ainda não conseguiu conquistar um campo 
próprio equivalente ao da sociologia do trabalho, por exemplo. Consequentemente, a sociologia não conseguiu antecipar a posição central que a desapropriação de terras ocupa na vida política e econômica de muitos países. Essa omissão caracteriza não só a sociologia do Ocidente, onde a desapropriação tem exercido um papel relativamente limitado na atualidade, mas também a sociologia de países emergentes, onde a desapropriação vem sendo um fenômeno significativo há muitas décadas. As principais abordagens macrossociológicas ao estudo do desenvolvimento negligenciaram em grande escala a desapropriação de terras rurais mediada pelo Estado, que acompanhou os "projetos de desenvolvimento" nacionais (McMichael, I996) nos meados do século XX.

É, de certa forma, curioso que a desapropriação de dezenas de milhões de pessoas pela modernização capitalista tenha escapado à atenção dos estudiosos da sociologia do desenvolvimento. Malgrado suas diferentes abordagens às condições sob as quais determinados países podem ser modernizados industrialmente e conquistar setores mais avançados do capitalismo global, poucos perceberam a desapropriação que acompanha esses esforços. Essa omissão pode, em parte, refletir a tendência clássica de abordar a economia política como interação abstrata de várias classes com o Estado em relação a salários, preços, subsídios e impostos. Pode refletir, também, o fato de a "fórmula da Trindade" de Marx ignorar o aluguel em prol do binarismo salário-lucro (Lefebvre, I99I; Coronil, I997). Como Lefebvre observa, a consequência dessas perspectivas é que "o espaço da prática social é imperceptível" (Lefebvre, I99I: 324). Argumentarei, contudo, que há também uma explicação sociológica para a negligência que a desapropriação vem sofrendo na sociologia.

As principais abordagens teóricas ao estudo do desenvolvimento foram formadas durante um período em que, como demonstrarei, a aquisição forçada de terra (na Índia e em muitos outros países em desenvolvimento) serviu a um projeto estatal de desenvolvimento nacional, legitimado significativamente pelo apoio de um público amplo, incluindo estudiosos de diferentes orientações políticas. Projetos para a construção de indústrias pesadas e de infraestrutura pública consumiram uma quantidade significativa de terra, mas essa desapropriação foi justificada como "sacrifício necessário para a nação". Esse tipo de apelo foi particularmente forte em países que estavam começando a emergir do domínio colonial e tentavam superar o "subdesenvolvimento" e construir economias nacionais autônomas. Mesmo não estando claro se tais justificativas sempre convenceram os desapropriados, sabemos que o grande apoio do público a tais projetos dificultava qualquer tipo de oposição. A ausência de qualquer resistência significativa à aquisição de terras na Índia ou em muitos outros países em desenvolvimento até a década de 1970 e especialmente a década de I980 (e sua marginalização contínua) ajuda a explicar por que a ciência social ignorou em grande parte o fenômeno da desapropriação de terras para o desenvolvimento não agrícola em regiões rurais. Muitas vezes, são as lutas polí- 
ticas que nos sensibilizam para fenômenos sociais e econômicos significativos, e a desapropriação não causou alvoroços. Ao desencorajarem qualquer resistência, os regimes desenvolvimentistas também desviaram a atenção sociológica da desapropriação.

\section{A EMERGÊNCIA DE ESTUDOS SOBRE REASSENTAMENTOS E TOMADAS DE TERRA}

Foi apenas nas décadas de 1970 e I980 - quando movimentos sociais bem organizados surgiram para resistir à desapropriação de terras para a construção de represas e outros projetos de desenvolvimento - que os estudiosos começaram a prestar atenção nesse fenômeno, ainda que à margem da sociologia. $\mathrm{Na}$ Índia, ativistas e estudiosos críticos começaram a documentar a luta das pessoas reassentadas por projetos de desenvolvimento, particularmente pelas grandes represas (por exemplo, Fernandes \& Thukral, I989; Thukral, I992; Fernandes \& Paranjpye, I997; Parasuraman, I999). Lutas pioneiras como o Narmada Bachao Andolan (Movimento "Salve o Narmada"), movimento popular que surgiu em oposição à represa Sardar Sarovar, no Vale de Narmada, colocaram o reassentamento forçado na agenda dos estudiosos e das agências de desenvolvimento internacionais. Projetos como o Sardar Sarovar se tornaram símbolos poderosos da crescente desilusão com os esforços top-down da modernização econômica. O Banco Mundial, exposto a críticas generalizadas em virtude de seu financiamento de projetos social e ambientalmente destrutivos, foi forçado a desenvolver estratégias para aquilo que chamou de "reassentamento involuntário". Contratou sociólogos e antropólogos para desenvolver "diretrizes para o reassentamento e a reabilitação" (ver Cernea, I999), contribuindo assim para a criação de uma literatura orientada pelas políticas de "reassentamento induzido pelo desenvolvimento". Sociólogos mais críticos na Índia, membros de uma corrente crescente de uma ecologia política marxista (por exemplo, Peet \& Watts, 2004[I996]; Peluso \& Watts, 200I), também começaram a desviar seu foco tradicional em "conflitos na fábrica e no campo" e voltá-lo para os "conflitos em torno de florestas e rios" (Baviskar, I995: 40; ver, também, Guha, I989). Essa literatura surgiu no encalço das lutas contra os projetos do Estado nehruviano (represas, projetos de mineração, projetos florestais do Estado, indústrias do setor público) e suas contrapartes em outros lugares nas décadas de I970 e I980; ela fornece o ponto de referência histórico para a comparação das desapropriações contemporâneas do período neoliberal.

A proliferação das "tomadas de terra" e os protestos contra estas na era neoliberal começou a exigir uma atenção pública e acadêmica mais ampla. De modo um tanto ortogonal em relação aos que vinham estudando a desapropriação há décadas em diferentes países (por exemplo, Baviskar, I995; Watts, 2004a [1996], 2004b; Hart, 2002; Moore, 2005), surgiu recentemente uma ampla litera- 
tura sobre os esforços de investidores privados e até mesmo países soberanos de adquirir áreas imensas de terra, particularmente na África e na América Latina, para plantações agrícolas, inclusive para produção de biocombustíveis. A maioria desses estudos não tenta desenvolver uma teoria da relação entre desapropriação e capitalismo, antes, emprega o termo "tomada de terra" de forma descritiva. No entanto, podemos identificar duas tendências nos estudos mais teóricos. A primeira é a tendência de generalizar excessivamente essa forma específica de desapropriação, sem levar em consideração o contexto social e histórico mais amplo da desapropriação para variados fins econômicos, induzindo assim conclusões equivocadas. Zoomers (2010), por exemplo, argumenta que o atual aumento de tomadas de terra transnacionais faria parte de um fenômeno contemporâneo mais amplo da "estrangeirização do espaço" e cita as zonas econômicas especiais (SEZ) da Índia como exemplo. Sassen (2013) conclui semelhantemente que as tomadas de terra participariam do "desmantelamento do território nacional". Veremos que as zonas econômicas especiais da Índia são desenvolvidas e financiadas domesticamente. A questão principal, porém, é que, ao desenvolver uma teoria da desapropriação, o foco na origem do capital que a impulsiona serve como distração: o capital representa apenas um dos fatores - e de importância apenas secundária em relação ao tipo de capital - que ajudam a explicar as variações no caráter e nas consequências da desapropriação em diferentes momentos e lugares. A segunda tendência tem sido um foco nas forças econômicas globais que, supostamente, estariam por trás da desapropriação, mas que ignora os meios políticos para a realização da mesma. Em outras palavras: os estudiosos têm dedicado muita atenção às mudanças no capitalismo agrícola global, que parecem ser responsáveis por essas tomadas de terra específicas, mas se interessaram muito pouco pelos meios exatos com que os Estados realizam a desapropriação para esses ou quaisquer outros fins - e como estes se distinguem de práticas estatais anteriores. Enquanto transformações no "regime de alimentação" global podem ajudar a explicar um dos motivos que impulsionam as "tomadas de terra" (McMichael, 20 I2; 20I3), apenas uma teoria de regimes domésticos de desapropriação pode nos ajudar a entender por que e como determinados Estados respondem a esse impulso com a desapropriação forçada de camponeses. Em geral, a literatura crescente sobre a "tomada de terra" não tem vinculado essa nova preocupação com os investimentos agrícolas transnacionais a uma teoria mais ampla da desapropriação de terras.

O primeiro passo na construção de uma teoria mais satisfatória sobre a relação entre capitalismo e a desapropriação de terras consiste em retornar à principal tradição teórica que possuía uma teoria da desapropriação. Os marxistas, juntamente com os sociólogos, certamente têm negligenciado (em teoria e prática) o problema do reassentamento de populações rurais pela indústria capitalista. No entanto, o marxismo possui uma teoria sobre a relação entre 
desapropriação e capitalismo. Essa teoria precisa ser substancialmente reconstruída antes que possa ser usada para entender as formas contemporâneas de desapropriação de terras, mas precisamos esclarecer essa herança teórica antes de demonstrar como o conceito de regimes de desapropriação difere dela.

\section{ACUMULAÇÃO PRIMITIVA A DESAPROPRIAÇÃO NA TRANSIÇÃO PARA O CAPITALISMO}

Existem basicamente duas abordagens marxistas ao estudo da desapropriação, e ambas derivam da teoria da "acumulação" primitiva de Marx. A primeira vertente se apoia na análise de Marx dos cercamentos ingleses, onde desenvolveu seu famoso argumento segundo o qual as origens do capitalismo se encontrariam no "processo histórico de isolar o produtor dos meios de produção" (Marx, I977: 875).

Para Marx, esse processo sangrento e violento de expulsar os camponeses da terra gerou as precondições para o capitalismo na Inglaterra rural, efetivando as "duas transformações pelas quais os meios sociais de subsistência e produção são transformados em capital; e os produtores imediatos, em trabalhadores assalariados" (Marx, I977: 875). Ao contrário do "conto de fadas" sobre as origens do capitalismo defendido por Adam Smith, Marx argumentou que as relações sociais capitalistas foram criadas "sob circunstâncias de terrorismo brutal" (Marx, I977: 895). Senhorios, a coroa e, eventualmente, também o parlamento recorreram à força bruta para cercar terras comuns, retirar as casas e seus donos do latifúndio, privatizar propriedade estatal e eclesiástica e criar um proletariado destituído, que agora estava "livre" para vender sua mão de obra - e que se via obrigado a fazê-lo, pois havia sido "libertado" de qualquer propriedade. Para Marx, o nascimento do capitalismo foi, portanto, muito menos idílico do que Adam Smith alegava; o capital veio ao mundo "com sangue e sujeira pingando de cada poro da cabeça aos pés” (Marx, I977: 926).

Alguns comentaristas têm observado que a "acumulação primitiva" de Marx representava mais um relato histórico contingente sobre o desenvolvimento capitalista na Inglaterra do que uma teoria elaborada (Balibar, I979: 279). Esse relato contingente apresenta duas ambiguidades importantes relacionadas aos modos de como conceber a acumulação primitiva. Por um lado, essa seção do Capital apresenta uma história de origem sobre como surgiram as precondições para o capitalismo. Desse ponto de vista, a acumulação primitiva é definida por sua função no desenvolvimento do capitalismo: representa aqueles processos históricos que inauguram as relações sociais capitalistas. Se extrairmos uma definição teórica desse relato, a "acumulação primitiva" pode ser tudo aquilo que gera essas relações por meio da proletarização de camponeses e estabelece uma classe capitalista provida de um "estoque" de capital para empregá-los, com ou sem "sangue e sujeira". No entanto, podemos interpretar 
a teoria da acumulação primitiva de Marx também como distinção específica entre os processos (não capitalistas) que possibilitam a emergência de um modo de produção capitalista, no qual "conquista, escravização, roubo, assassinato, ou seja, violência exerceu o maior papel” (Marx, I977: 874), e um sistema capitalista maduro que, uma vez desenvolvido, dispensa a coerção extraeconômica e confia na "compulsão silenciosa das relações econômicas" (Marx, ı977: 899). Na primeira definição, é a função que distingue a acumulação primitiva da acumulação capitalista - ela gera as precondições do capitalismo antes de o capitalismo assumir o poder e recriar internamente suas próprias condições. Na segunda definição, são os meios extraeconômicos da acumulação primitiva que a separam da acumulação capitalista propriamente dita.

Disso surge uma segunda ambiguidade. Quanta ênfase devemos colocar em cada uma das "duas transformações": da terra em capital e dos camponeses em proletariado? Marx devota menos atenção às forças econômicas que motivaram a aristocracia rural a transformar as terras comuns em pastos para ovelhas do que às suas consequências (involuntárias): a criação de uma classe de trabalhadores assalariados "libertos" de seus meios de produção. Essa ênfase é lógica em vista da concepção de Marx do marxismo e do papel histórico que ele atribui ao proletariado. Se, porém, destacássemos a primeira transformação, não seria a acumulação primitiva um processo contínuo ao passo que o capitalismo crescente - com uma oferta já ampla de trabalhadores assalariados demandasse cada vez mais terra e recursos naturais? Mesmo que alguns tenham argumentado contra essa visão, é bastante claro que o próprio Marx confinou a acumulação primitiva a um capítulo inicial do desenvolvimento do capitalismo. Marx a chama de "acumulação que não resulta do modo capitalista de produção, antes é seu ponto de partida" (Marx, I977: 873). A acumulação primitiva cria as pressuposições do capital; uma vez estabelecido, o capitalismo recria suas próprias condições de existência na base do trabalho assalariado. $\mathrm{Na}$ medida em que avança, ele o faz de modo serial, enquanto outros países adotam o capitalismo.

Na verdade, o "caso clássico" dos cercamentos ingleses conseguiu ocultar a ambiguidade entre "função e meios" porque nele ambas as definições coincidiam: na visão de Marx, uma força extraeconômica estabelecia as precondições do capitalismo. Mas quando os historiadores acataram a análise de Marx da acumulação primitiva na Inglaterra e os cientistas sociais a aplicaram a "transições capitalistas" sob outras condições históricas, essa ambiguidade teve repercussões graves para a coerência teórica da acumulação primitiva.

Em primeiro lugar, surgiu um debate significativo sobre o papel dos cercamentos no desenvolvimento do capitalismo na Inglaterra. Maurice Dobb (I947) e Robert Brenner (I976, I977) defenderam e aprofundaram sua importância. No entanto, seus argumentos foram criticados não só por historiadores ingleses tradicionais, mas também por outros marxistas que rejeitavam a iden- 
tificação das origens do capitalismo nas relações da classe agrícola da Inglaterra (Sweezy, I978; Wallerstein, I974, 20 I [ [1989]). A ambiguidade, porém, que surgiu em relação à importância específica dos cercamentos de terras dentro do grupo que, de fato, identificava que as origens do capitalismo na Inglaterra rural do século XVI teve consequências talvez ainda mais sérias. Em teorias subsequentes mais refinadas da posição de Brenner, não foi a desapropriação de terras, mas a redução à "dependência do mercado" que sinalizou a ascensão das relações sociais capitalistas (Brenner, 200I; Wood, 2002). Esse argumento suscita a pergunta se a acumulação primitiva inclui necessariamente a desapropriação de terras.

Essa pergunta surge também na ampla literatura sobre transições para a agricultura capitalista em outras partes do mundo. Décadas de pesquisas sobre a "questão agrária" demonstraram que o cercamento de terra muito difundido constitui apenas um caminho historicamente específico para o desenvolvimento capitalista (Byres, I99I). Consequentemente, a acumulação primitiva passou a adotar dois sentidos nessa literatura: podia referir-se a qualquer processo que isolava o camponês de seus meios de produção, transformando-o em proletariado e gerando, ao mesmo tempo, uma classe de capitalistas agrários. Muitas vezes, isso não acontecia por meio de um despejo em grande escala, mas por meio de um processo gradual de diferenciação de classes gerada pela agricultura comercial (Lenin, I967; Kautsky, I 988: I7; Adnan, I985: 57). Processos econômicos como o endividamento vieram a ser vistos como instrumentos tão eficazes de acumulação primitiva quanto o cercamento extraeconômico de terras (Bhaduri, I983). Mas a acumulação primitiva podia se referir também ao processo geral de desviar excedentes agrícolas para a industrialização capitalista (Byres, I99I: I I). Nesse sentido, a acumulação primitiva não significava necessariamente o estabelecimento de relações sociais capitalistas na agricultura, mas a transferência de excedentes da agricultura para a indústria. Nesse emprego, a acumulação primitiva representava uma condição necessária para o crescimento econômico em todos os países "atrasados", inclusive os países socialistas (Preobrazhensky, I965; Ka \& Selden, I986; Byres, I99I: I I).

Resumindo: a ampla pesquisa sobre as origens do capitalismo e as transições agrárias na Europa e no Hemisfério Sul ampliou as ambiguidades originais no conceito da acumulação primitiva de Marx. Já não está mais claro se a acumulação primitiva se refere à desapropriação de terra através de meios extraeconômicos, a qualquer processo que gere as precondições do capitalismo ou até mesmo a qualquer processo que fornece excedentes para a industrialização. Não pretendo averiguar se os cercamentos de terra foram realmente de importância central para as origens do capitalismo ou para as transições capitalistas subsequentes, tampouco questionarei se esses empregos do conceito da aquisição primitiva são realmente úteis. Podemos também ignorar por ora a dificuldade que tem acompanhado seu emprego empírico, dificuldade esta 
que surge do problema de demonstrar onde modos não capitalistas de produção recuam diante de modos capitalistas (Roseberry, I994: I62; Hall, 20 I2). O propósito desta discussão é, antes, ilustrar que a lente conceitual da "acumulação primitiva" é inadequada para compreender a relação entre capitalismo e formas contínuas de desapropriação de terras. Isso se deve principalmente ao fato de que as desapropriações atuais não podem ser compreendidas no antigo sentido funcional segundo o qual elas criariam as precondições do capitalismo: elas não inauguram necessariamente relações sociais capitalistas e não representam transições entre modos de produção. Muitas vezes, têm muito pouco a ver com a agricultura ou com uma resolução da "questão agrária". Muitas vezes, a desapropriação das terras - às vezes, já retidas dentro de relações sociais capitalistas - ocorre em prol de um desenvolvimento não agrícola. Essa desapropriação não reflete uma fase inicial do capitalismo, mas reivindicações capitalistas avançadas de terras e recursos naturais. Assume uma miríade de formas específicas em cada setor - sejam elas represas, estradas, minas, usinas siderúrgicas, zonas econômicas especiais ou projetos de habitação - que em nada se parecem com o padrão "clássico" do cercamento. Precisam ser compreendidas no contexto de uma nova problemática: a questão não é a função da desapropriação de terras na transição para o capitalismo, mas a função da desapropriação de terras no próprio capitalismo. Isso exige, como tentarei demonstrar, uma atenção voltada aos "regimes de desapropriação", e não aos "modos de produção". Antes, porém, de desenvolvermos essa estrutura, precisamos contemplar as limitações da segunda abordagem "externalista” à acumulação primitiva.

\section{DESAPROPRIAÇÃO COMO IMPERIALISMO}

Além dos cercamentos, o catálogo de Marx de "acumulação primitiva" incluía uma série de outros processos que não diziam respeito primariamente à estrutura agrária doméstica da Inglaterra, mas à sua relação com o resto do mundo:

A descoberta de ouro e prata na América, a extirpação, a escravização e o sepultamento da população indígena nas minas daquele continente, os inícios da conquista e do saqueio da Índia e a conversão da África em uma reserva para a caça comercial a peles negras - tudo isso são coisas que caracterizam a aurora da era da produção capitalista. Esses procedimentos idílicos são os momentos principais da acumulação primitiva (Marx, 1977: 915).

Nessa concepção externa, a acumulação primitiva não se refere ao estabelecimento de relações sociais capitalistas na Inglaterra, mas a um acúmulo inicial de riqueza por meio do saqueio colonial, da escravidão e da conquista genocida. Como já na análise de Marx dos cercamentos domésticos, não está claro se esses processos constituem uma acumulação primitiva pelo fato de cumprirem a função de criar as precondições para o capitalismo (aqui, a 
ênfase está mais em repatriar um "estoque" de capital para facilitar o início da acumulação capitalista, e menos em criar um proletariado) ou pelo fato de envolverem meios violentos e extraeconômicos. Em todo caso, as teorias marxistas subsequentes acataram esse lado externo da acumulação primitiva (Luxemburgo, 2003 [I9I3]). Ao minimizarem a importância dos processos internos da acumulação primitiva, os estudiosos da dependência e dos sistemas mundiais avançaram ainda mais esse foco externo (Sweezy, I978; Wallerstein, I974, 20I I [I989]; Arrighi, I994). Visto que a concepção interna da acumulação primitiva não nos fornece uma teoria praticável sobre a relação entre capitalismo e a contínua desapropriação de terras, essas teorias de imperialismo e saqueio interestatal conseguem oferecer uma alternativa?

Para começar, precisamos entender que as primeiras teorias marxistas sobre o imperialismo representavam tentativas de explicar por que as dinâmicas internas do desenvolvimento capitalista em países "avançados" levaram à exportação de capital, à expansão territorial, à rivalidade interimperialista e à guerra (Hildferding, I98I [I9Io]; Bukharin, I973 [I9I7]; Lenin, I929 [I9I7]). Deram pouca atenção às regiões "coloniais" como objeto dessa competição (Brewer, I990), e havia diferenças de opinião significativas em relação à sua importância econômica exata (Arrighi, I978). Mesmo que a necessidade de recursos naturais tenha recebido uma atenção ocasional, os teóricos enfatizaram mais a necessidade de acesso a novos mercados para os monopólios capitalistas nacionais. Visto que é o controle político sobre territórios que permite aos capitalistas nacionais a expansão de seus mercados protegidos, é isso que motiva as teorias marxistas "clássicas" sobre o imperialismo. Rosa Luxemburgo foi a exceção proeminente: sua teoria do imperialismo vinculava as dinâmicas da acumulação capitalista explicitamente à contínua "acumulação primitiva" de terras de sociedades não capitalistas. Baseando-se numa teoria de "subconsumo" - da incapacidade de realizar um valor capitalista excedente dentro do capitalismo em virtude de uma demanda ineficaz -, ela sugeriu que o capitalismo precisava do emprego contínuo de violência contra as sociedades não capitalistas a fim de conseguir acesso a seus mercados e meios de produção:

É uma ilusão esperar que o capitalismo se conforme com os meios de produção que consiga adquirir por meio do comércio de mercadorias. Já nesse ponto, o capital se depara com dificuldades, pois vastas zonas da superfície da terra já se encontram em posse de organizações sociais que não demonstram qualquer desejo pelo comércio de mercadorias ou não podem - em virtude de toda a estrutura social e das formas de propriedade - oferecer para a venda as forças produtivas pelas quais o capital se interesse em primeira linha [...]. Daí a necessidade vital do capital em suas relações com países coloniais de apropriar-se dos mais importantes meios de produção. [...] Violência é a única solução que se apresenta ao capital; a acumulação de capital, vista como processo histórico, emprega a violência como uma arma permanente, não apenas em sua gênese, mas até os dias de hoje (Luxemburgo, 2003 [19I3]: 35I). 
Segundo Luxemburgo, o capitalismo depende, portanto, do emprego contínuo da violência extraeconômica contra um exterior não capitalista, que ele precisa consumir progressivamente como condição de sua existência. O saqueio da Índia, as guerras de ópio e a destruição do pequeno fazendeiro americano são os principais exemplos que Luxemburgo cita para essa acumulação primitiva contínua. Ela acreditava que era apenas uma questão de tempo até que o capitalismo devorasse todo o meio social não capitalista que o sustentava, causando assim uma série crescente de crises e convulsões políticas (Luxemburgo, 2003, [I9I3]: 447).

Embora sua teoria de "subconsumo" tenha sido muito criticada, e sua representação das sociedades pré-capitalistas dominadas por uma "economia natural", comprovadamente inadequada, sua conclusão continua válida: os capitalistas percorreriam o planeta em busca de meios de produção baratos e usariam violência contra eles. Luxemburgo foi a primeira a enxertar o relato histórico contingente de Marx sobre a acumulação primitiva em uma teoria da acumulação capitalista, transformando-a de um "pecado original" em um processo continuado. Veremos que isso serviu como inspiração direta para a teoria da "acumulação por desapropriação" de David Harvey, da qual parte a minha própria teoria.

Se os teóricos subsequentes da dependência e de sistemas mundiais passaram a focar com intensidade ainda maior nos vínculos políticos e econômicos exploradores entre países capitalistas avançados e o resto do mundo, o papel que a desapropriação de terras exerce nessas teorias é mais ambíguo do que em Luxemburgo. Por um lado, essa tradição notoriamente minimizou a importância da desapropriação de terras para o desenvolvimento do capitalismo dentro dos países (Wallerstein, 20 I [ [1989]) e questionou seu vínculo com o desenvolvimento econômico de longo prazo (Arrighi \& Pisselli, I987; Arrighi, 2007; Arrighi, Aschoff \& Scully, 2010). Visto que esses teóricos não definem o capitalismo por meio da relação do trabalho assalariado, eles não levam em consideração processos domésticos como os cercamentos ingleses, significativos para a identificação das origens do capitalismo ou até mesmo para a facilitação de acumulação capitalista. Por outro lado, muitos dos seus teóricos alegam que a incorporação ao sistema mundial e sua divisão de trabalho envolve a transformação das relações de propriedade (Wallerstein, 20 I I [ I989]: I48-I79) e catalogaram o saqueio interestatal de recursos como uma dimensão da transferência de riqueza da periferia para o núcleo (Frank, I979: esp. Io, 23, I46, I60-I6I; Arrighi, I994: 54). Permanece difuso o lugar que o saqueio de recursos e a desapropriação física de terras ocupa nessas teorias, principalmente em comparação com outros mecanismos de transferência de excedentes, como, por exemplo, a "troca desigual". Em todo caso: enquanto a primeira teoria "internalista" da acumulação primitiva focava na função da desapropriação de estabelecer relações sociais capitalistas, a teoria "externalista" focava na 
desapropriação como função de absorção num mercado capitalista global e sua divisão de trabalho.

Essa abordagem "externalista" possui várias vantagens. Em primeiro lugar, identifica o saqueio interestatal como eixo histórico significativo da desapropriação. Independentemente de esse saqueio ter sido crucial ou não para o desenvolvimento do capitalismo no Ocidente, ele enfatiza a primeira das "transformações de Marx"; ou seja, ele destaca as forças econômicas por trás das desapropriações de terra, em vez de limitar seu foco à consequência incidental da criação de um proletariado. Isso parece fornecer uma base para entender a acumulação primitiva como processo contínuo (e não apenas como transição para o capitalismo). Em segundo lugar, a teoria "externalista" desvincula o processo da acumulação primitiva da concepção do progresso econômico. As abordagens das teorias de dependência e sistemas mundiais destacavam o fato de que as relações econômicas políticas - ao ligarem o núcleo à periferia, incluindo a acumulação primitiva de recursos - não representava uma fase progressiva no desenvolvimento do capitalismo, como alegavam alguns marxistas (Warren, I980). Antes, geravam desenvolvimento no núcleo e subdesenvolvimento na periferia. Embora eu não limite minha análise da desapropriação ao saqueio interestatal e não insista na alegação segundo a qual isso resultaria em subdesenvolvimento, insisto sim - juntamente com Arrighi e coautores, mesmo que por razões diferentes - na posição segundo a qual a desapropriação não apresenta um vínculo necessário com o progresso econômico. A contribuição da desapropriação para o desenvolvimento é, antes, uma variável histórica; defenderei que ela apresenta variações entre os diferentes regimes de desapropriação.

Mesmo assim, o papel da desapropriação no capitalismo nunca alcançou o nível de uma teoria na análise da dependência ou dos sistemas mundiais, e diversas falhas acometem as proposições existentes. Em primeiro lugar - como argumenta Brenner (I977) -, Frank e Wallerstein não conseguem explicar as transformações nas relações sociais de propriedade de terras, mas supõem que estas resultam das "necessidades" do sistema mundial. Não fornecem nenhuma justificativa para os processos políticos domésticos e da luta de classes necessária para efetuar mudanças de longo alcance nas relações de propriedade. Apesar de argumentar, contra Brenner, que a desapropriação exerce um papel significativo no capitalismo plenamente desenvolvido (e não só em sua origem), desenvolvo seu conceito de desapropriação como um processo contingente profundamente político para o equilíbrio das forças de classes. Em segundo lugar, os teóricos da dependência do sistema mundial veem o saqueio extraeconômico como uma relação externa entre núcleo e periferia. Não analisam a desapropriação como um processo interno contínuo do desenvolvimento capitalista de qualquer país. Como veremos, as desapropriações de terras participam tanto do desenvolvimento capitalista sob condições relativamente autônomas de industrialização (para substituir a importação) quanto do colonialismo ou neolibera- 
lismo. As forças políticas econômicas por trás da desapropriação podem partir do capital doméstico ou do capital global. A origem do capital é uma variável na formação de processos de desapropriação, mas não é um fator essencial a uma teoria geral do papel da desapropriação no capitalismo.

Em resumo: a abordagem "externalista" à "acumulação primitiva" identifica corretamente a existência de desapropriações contínuas que resultam de um capitalismo já desenvolvido e separa essas desapropriações de um conceito de progresso. No entanto, limita a desapropriação a uma relação entre países dentro do sistema mundial e negligencia seu papel no desenvolvimento interno do capitalismo de qualquer país específico (seja ele periférico ou não). O mais importante, porém, é que ela não examina os mecanismos políticos subsistentes em determinados Estados, que facilitam a desapropriação de terra por uma variedade de razões econômicas e que transferem a riqueza das classes rurais para outras classes capitalistas - nacionais ou estrangeiras.

Juntas, as abordagens interna e externa à "acumulação primitiva" não conseguem explicar completamente o papel da desapropriação de terra no desenvolvimento capitalista. A posição internalista permanece ambígua em relação ao papel da desapropriação de terra na acumulação primitiva e, além disso, confina a acumulação primitiva ao estabelecimento inicial do capitalismo nos países. A posição externalista identifica de forma descritiva as desapropriações contínuas entre países, mas negligencia seu papel interno; além do mais, permanece ambígua em relação à importância geral da desapropriação na transferência transnacional de riqueza. Ao focarem na pergunta se os impulsos para a desapropriação partem de fontes domésticas ou globais, nenhuma abordagem consegue elucidar as relações políticas que viabilizam a desapropriação, não importa o momento, o lugar ou o propósito. Nenhuma nos fornece um meio de compreender os esforços contínuos dos Estados de desapropriar a terra das populações rurais em prol da indústria, da infraestrutura ou de bens imóveis. A teoria de acumulação por desapropriação, de David Harvey, preenche essa lacuna.

\section{ACUMULAÇÃO POR DESAPROPRIAÇÃO}

Em The new imperialism (2003), Harvey argumenta que a "acumulação por desapropriação" se transformou em modo predominante de acumulação sob o neoliberalismo e que o foco marxista tradicional no trabalho precisa ser complementado por uma atenção maior voltada para as lutas contra a desapropriação de várias formas de riquezas públicas e privadas. Os exemplos de acumulação por desapropriação citados por Harvey incluem a expropriação de terra e recursos naturais de populações camponesas, a conversão de propriedade comunal ou estatal em propriedade privada, a extração de aluguéis de direitos de propriedade intelectual, a privatização de bens sociais coletivos 
(como pensões, saúde pública e outros direitos sociais) e as várias predações do capital financeiro. Harvey vê a reemergência da importância desses mecanismos relativos à "reprodução expandida" como reação ao problema do capital superacumulado nas economias centrais do Norte.

Um mérito enorme da teoria da acumulação por desapropriação de Harvey é que ela fornece um termo diferente para as expropriações que ocorrem dentro do capitalismo avançado. A acumulação por desapropriação liberta a noção da acumulação primitiva dos interstícios dos modos de produção, tornando-o um conceito mais versátil capaz de explicar formas bem distintas de desapropriações, que pouco têm em comum com a agricultura e que não inauguram necessariamente relações sociais capitalistas: por exemplo, desapropriações para fábricas, represas, zonas econômicas especiais, destruição de favelas, projetos de mineração, infraestrutura privatizada e projetos de habitação. Mesmo que alguns tenham tratado a acumulação primitiva e a acumulação por desapropriação como sinônimos (Arrighi, Aschoff \& Scully, 20IO: 4I I), a acumulação por desapropriação representa um avanço significativo em relação à acumulação primitiva, justamente em virtude de sua capacidade de compreender diversas desapropriações contemporâneas em suas formas específicas aos seus setores e localizações geográficas dispersas e cuja relevância para o capital - pelo menos em seu sentido aproximado - se encontra mais no bem expropriado do que no dono desapropriado (a primeira das transformações de Marx). Não que a mudança terminológica seja necessária para a renovação de seu conceito - outros estudiosos antes e depois de Harvey têm defendido conceitos de uma "acumulação primitiva contínua" que marcam uma ruptura semelhante (Luxemburgo, 2003[I9I3]; Perelman, 2000; De Angelis, 200I; Hart, 2002; Retort, 2005; De Angelis, 2007; Sanyal, 2007). No entanto, o termo confere uma validade contemporânea ao conceito, deixando claro que ele já não se refere mais à "pré-história" do capital (Marx, I977: 875) ou a transições agrárias únicas no Hemisfério Sul.

O que, exatamente, define a acumulação por desapropriação? Ao libertar a acumulação primitiva de sua função de gerar relações sociais capitalistas, Harvey redefine o conceito com a ajuda de outra função mais contemporânea, ou seja, a de absorver capital superacumulado na economia global. Ele chega a fornecer uma definição que abarca os diversos processos que descreve. Harvey afirma: "O que a acumulação por desapropriação faz é liberar uma série de recursos (inclusive a mão de obra) a custos muito baixos (às vezes, até a custo zero). Capital superacumulado pode apoderar-se desses recursos e transformá-los imediatamente em uso lucrativo" (Harvey, 2003: I49). Sem a referência a processos que geram as precondições do capitalismo, a acumulação por desapropriação indica um conjunto de processos que permitem ao capital global encontrar novos mercados. Numa extensão autoconsciente da análise do imperialismo de Luxemburgo, Harvey tenta localizar a necessidade de desa- 
propriações contínuas dentro da lógica contraditória da própria acumulação capitalista. No entanto, enquanto Luxemburgo considerava essa contradição um problema do "subconsumo", Harvey a vê como problema da superacumulação: a redução de oportunidades para investimentos lucrativos em países capitalistas avançados obrigou o capital excedente a procurar novos mercados. A desapropriação fornece um mercado para esse capital ao trazer ativos não mercadizados, antes até "desmercadizados", ou subvalorizados para a órbita da acumulação capital.

O que Harvey fez foi, então, tomar os aspectos interno e externo da acumulação primitiva descrita por Marx e argumentar que eles continuam presentes no capitalismo avançado, não pelo fato de gerarem as precondições do capitalismo, mas por serem, eles mesmos, as condições para sua expansão contínua. A acumulação por desapropriação representa uma reunião parcial das abordagens interna e externa, pois inclui processos de cercamento agrário realizados por estados domésticos (para represas, zonas econômicas especiais etc.), arraigando-os numa lógica do capital global, no qual os países do Norte continuam sendo seus agentes principais (permanecendo assim, em última análise, uma teoria de imperialismo). No entanto, mesmo que Harvey atribua a desapropriação a uma função mais nova e mais contemporânea do que Marx, ele preserva intacta a ambiguidade fundamental de Marx: a acumulação por desapropriação é definida pela sua função para o capital ou pelos meios específicos a ela?

Esperaríamos que Harvey especificasse a acumulação por desapropriação como processos que fornecem mercados para o capital através de meios extraeconômicos - como na caracterização de Marx da acumulação primitiva que envolve "conquista, escravização, roubo, assassinato, ou seja, violência" (I977: 874) ou como na afirmação de Luxemburgo, segundo a qual o capitalismo "emprega a violência como arma permanente" (2003 [I9I3]: 369). A definição da acumulação por desapropriação como acumulação através de meios extraeconômicos (ver Glassman, 2006) abarcaria muitos dos exemplos citados por Harvey: represas, zonas econômicas especiais, destruições de favelas e várias formas de cercamento mediadas pelo Estado, privatizações e transferências de riqueza pública. No entanto, Harvey não só não fornece uma definição clara da acumulação por desapropriação, como também refuta a definição acima, alegando que a acumulação por desapropriação é "primariamente econômica, e não extraeconômica" (Harvey, 2006: I59). Sem essa distinção de meios, porém, não fica claro o que esses processos diferentes têm em comum, nem o que distingue a acumulação por desapropriação de outras "soluções" para o problema da superacumulação ou da reprodução expandida "normal" do capital (ver Brenner, 2006; Levien, 20I I; 20I2). O limite do conceito é corrompido; e sua utilidade analítica, minada.

A consequência disso é que Harvey subestima o aspecto mais significativo da desapropriação, ou seja, o fato de ela ser um processo profundamente 
político pelo qual os detentores dos meios de coerção redistribuem de forma transparente os ativos de uma classe para outra. Apesar de reconhecer que a força estatal pode exercer um papel central na desapropriação (Harvey, 2003: I54), ele abusa do conceito ao incluir nele tantos fenômenos diversos - inclusive o capital financeiro que apresenta um vínculo indireto ou confuso com a força estatal - de maneira que não consegue incorporar o Estado de forma explícita à sua teoria. Em consequência disso, o quadro de referências de Harvey acaba ignorando o aspecto crucial e diferenciador da acumulação por desapropriação quando aplicada à terra: sua dependência fundamental e transparente do poder estatal. Isso impede que ele entenda a política distintiva da desapropriação.

Como processo de redistribuição transparente e coerciva, a desapropriação de terras é um processo político contingente cujo resultado é determinado pela luta de classes e não pelos circuitos do capital (Brenner, I977; De Angelis, 2007). Não há nada de automático quando o capital (superacumulado ou não) descobre a terra ou qualquer outro ativo como novo mercado; ao interpretar cada instância de desapropriação como resultado dos impulsos globais do capital, Harvey não consegue responder à pergunta por que impulsos em direção à acumulação resultam na desapropriação em determinado contexto. Por que os capitalistas precisam do Estado para que este desaproprie terra para eles? Por que não a adquirem simplesmente no mercado? E por que os Estados fazem isso por eles? A desapropriação requer um Estado que esteja disposto e capaz de usar seu monopólio de meios de violência para expropriar a terra de determinadas classes para o benefício de outras. Veremos que, em parte, a desapropriação surge do desejo dos Estados de ajudar os capitalistas a vencerem os obstáculos no caminho para acumulação, como, por exemplo, mercados de terra rural dominados por pequenos fazendeiros camponeses. Mas, em tempos e lugares diferentes, vemos que os Estados têm sido dispostos e capazes de desapropriar terras para classes (ou frações de classes) diferentes para propósitos econômicos diferentes. Na Índia, o Estado colonial desapropriou terras para ferrovias e para a extração de recursos naturais para o benefício do capital metropolitano; o Estado nehruviano desapropriou terras para a indústria e a infraestrutura do setor público; e o Estado neoliberal desapropria terra para todas as formas de acumulação privada, inclusive bens imóveis. Hoje, a Índia e a China desapropriam terra em grande escala para fins urbano-industriais, enquanto os Estados africanos e latino-americanos tendem a desapropriar terras para plantações agrícolas. O conceito de Harvey oferece um fundamento fraco para compreender essa variação. Embora possa ser verdade, como argumenta, que a quantidade de desapropriações aumente com a instituição de políticas econômicas neoliberais (é o que acontece na Índia), permanece incerto e provavelmente impossível demonstrar que o capital superacumulado no Hemisfério Norte seja a causa disso. Repito: os acumuladores por desapropriação são, muitas vezes, domésticos (como é o caso nas zonas econômicas especiais da Índia). 
O que o cientista social precisa explicar - e que Harvey não faz - de forma mais fundamental é por que e como os Estados se reestruturam para desapropriar terra para fins e classes diferentes em diferentes momentos da história.

Precisamos explicar também como os Estados conseguem ser bem-sucedidos na desapropriação das pessoas por qualquer conjunto de fins e quais os fatores responsáveis pela variação nesse sucesso. $\mathrm{O}$ aspecto mais significativo da desapropriação de terra é que ela envolve a intervenção direta e transparente do Estado no processo de acumulação. Do ponto de vista político, essa intervenção direta e extraeconômica na acumulação gera um antagonismo imediato entre o Estado e a população a ser desapropriada. Os fazendeiros reconhecem claramente o que está acontecendo quando o Estado tenta despojá-los de sua terra; a desapropriação de terras é universalmente e imediatamente transparente (De Angelis, 2007: I39). Impedidos de se apoiar na mistificação comum à exploração do trabalho no capitalismo, os Estados são normalmente compelidos a justificar essas expropriações de terra tão evidentes por meio de reivindicações ideológicas: de servirem a "um propósito público" ou ao "interesse nacional"; no século passado, eles costumavam fazê-lo por meio da linguagem do "desenvolvimento". A força de persuasão dessas reivindicações depende consideravelmente da capacidade de alinhar o propósito econômico dessas desapropriações com um conceito amplamente aceito de progresso nacional. Quando as justificativas ideológicas e/ou as compensações materiais provam ser inadequadas e assim suscitam resistências, a capacidade do Estado de desapropriar é decidida pelo equilíbrio doméstico das forças políticas.

$\mathrm{Na}$ acumulação por desapropriação, então, o Estado, a política e a ideologia são - como Perry argumenta no contexto de modos pré-capitalistas de produção (1974: 403-404) - aspectos internos e constitutivos da própria acumulação. Essa é a implicação de enorme importância do reconhecimento segundo o qual a coerção extraeconômica, concebida como algo que se ameniza com a transição para o capitalismo, é, na verdade, um aspecto intrínseco e contínuo da acumulação no capitalismo avançado. Isso significa que o caráter e o resultado da desapropriação em momentos e lugares diferentes são formados por fatores políticos, econômicos e ideológicos heterogêneos e nacionalmente específicos que não podem ser deduzidos de circuitos globais do capital. Sua configuração específica em determinado lugar e momento pode ser compreendida como um regime de desapropriação.

\section{REGIMES DE DESAPROPRIAÇÃO}

Enquanto o esforço de definir a desapropriação por meio de seu papel funcional no capitalismo torna os conceitos da acumulação primitiva e da acumulação por desapropriação vagos e inutilizáveis, o conceito de "regimes de desapropriação" nos incentiva a começar pela análise dos meios distintos de desa- 
propriação. Em vez de começarmos com uma teoria do papel histórico da desapropriação ou com a pergunta se ela é motivada interna ou externamente, sugiro que comecemos com aquilo que caracteriza a desapropriação como processo social em qualquer contexto. A desapropriação é, basicamente, o uso de coerção extraeconômica para expropriar ativos não relacionados ao trabalho de um grupo para o benefício de outro. Quem sofre a desapropriação, quem recebe o ativo desapropriado e como o ativo é usado para a acumulação - tudo isso assume formas diferentes em tempos e espaços diferentes. A identificação dessa variação deveria ser o objeto de pesquisas comparativas. Quando detentores de meios de coerção desapropriam determinados grupos para o benefício de outro grupo de forma consistente para uma gama coerente de propósitos, podemos chamar isso de um "regime de desapropriação". Visto que, na maioria das circunstâncias, os Estados são os agentes principais da desapropriação e, além disso, apresentam a probabilidade maior de apresentar uma consistência em seus padrões de desapropriação, o conceito dos regimes de desapropriação será útil principalmente para compreender a desapropriação mediada pelo Estado, em oposição à desapropriação realizada por detentores menos centralizados de meios de coerção - máfias, milícias, gangues armadas ou senhorios "com seus pequenos métodos independentes" (Marx, I977: 885).

Se um regime de produção (ou um regime de fábrica) representa um meio institucionalizado para extrair trabalho extra de trabalhadores (Burawoy, I985), um regime de desapropriação representa um meio institucionalizado para expropriar ativos de seus donos ou usuários atuais. Ele apresenta dois componentes essenciais: um Estado disposto a desapropriar em nome de um conjunto específico de propósitos econômicos vinculados a interesses de classes específicos e um meio de gerar consentimento a essa desapropriação. Esses dois estão intrinsecamente interligados.

\section{DESAPROPRIAÇÃO E O ESTADO}

Em qualquer período determinado, os Estados possuem um conjunto de propósitos econômicos em nome dos quais estão dispostos a desapropriar terra. Quando se trata de desapropriar terra em domínio privado, isso representa em parte uma questão legal referente àquilo que é considerado um "propósito público" sob estatutos de domínio relevantes e leis domésticas (terra comunal é, muitas vezes, desapropriada com pouca resistência legal). No entanto, permanece uma questão primeiramente política, já que, como veremos, os Estados adaptam (e, às vezes, desconsideram) essas leis aos seus propósitos; e também porque Estados podem optar por não desapropriar terra em nome de todos os propósitos que a lei lhe permitiria. Alguns podem achar que se trata de uma "questão irrelevante" partindo da suposição de que os Estados são sempre instrumentos da classe dominante e, por isso, estão sempre dispostos a desapro- 
priar tudo que essa classe desejar. Na verdade, o fundamento de classe de um Estado não transparece em nenhuma outra área com tanta clareza quanto no processo de desapropriar meios de produção de um grupo e de entregá-los a outro. No entanto, ao pressupor que a disposição do Estado de desapropriar resulta automaticamente das "necessidades" do capitalismo suprime uma variação importante. Em primeiro lugar, a maioria dos Estados tem limitado a desapropriação forçada de terra de seus próprios cidadãos para "propósitos públicos", interpretados estritamente como projetos do Estado (Reynolds, 20Io). Enquanto algumas classes inevitavelmente lucram mais do que outras com projetos estatais, é necessário distinguir entre a desapropriação de terra para a infraestrutura pública e a desapropriação de terra em benefício direto do capital privado. Veremos que esta última caracteriza regimes históricos específicos, cuja emergência precisamos explicar. Em segundo lugar, as classes e frações de classes dominantes mudam ao longo de diferentes fases do capitalismo; assim, os tipos de acumulação que elas propõem para a terra desapropriada mudam com elas. Essa variação é importante. A desapropriação de terra para o capital industrial gera resultados (econômica e politicamente) diferentes do que a desapropriação de terra para o capital financeiro. Cada uma terá diferentes consequências subsidiárias para as classes não dominantes, incluindo os desapropriados. A fim de compreender os diferentes regimes de desapropriação, o cientista social precisa examinar as configurações de classes precisas subjacentes à desapropriação em qualquer contexto específico.

O campo de marxistas "externalistas" talvez objete que esse foco em regimes domésticos de desapropriação ignora a natureza global do capitalismo. Evidentemente, as forças econômicas globais moldam os propósitos econômicos em nome dos quais as diferentes classes desejam que o Estado desaproprie a terra. No entanto, essas forças globais interagem com estruturas sociais domésticas para produzir diferentes composições setoriais de crescimento econômico ligadas a diferentes alinhamentos de classe em países e tempos diferentes. Os regimes de desapropriação nos obrigam a começar não com uma explicação econômica política global para todo tipo de desapropriação em todos os lugares, mas com os propósitos econômicos específicos que motivam a desapropriação em tempos e lugares específicos; a partir daí, o sociólogo precisa alcançar níveis mais altos através do processo mais penoso da pesquisa comparativa. Ao passo que a sociologia da desapropriação avança, poderemos dizer mais sobre as transformações sofridas pelo caráter da desapropriação em escala global.

Por fim, devemos sempre manter em mente que os Estados se deparam com limites políticos em sua capacidade de desapropriar terra para os propósitos que escolherem; e os propósitos que escolherem para a desapropriação de terra têm implicações significativas para sua capacidade de executá-la. 


\section{CONSENSO E A POLÍTICA DE DESAPROPRIAÇÃo}

Todo regime de desapropriação necessita de uma maneira de compelir aqueles que atualmente controlam os desejados meios de desapropriação ou subsistência a desistirem deles. Precisamos começar distinguindo essa relação de poder de outros tipos - principalmente da exploração de trabalho - aos quais os sociólogos têm dedicado uma atenção muito maior. Primeiro, precisamos reconhecer precisamente o que um desapropriador exige do desapropriado e como isso difere daquilo que um capitalista exige do trabalhador. Enquanto a exploração de trabalho exige que o trabalhador trabalhe continuamente para produzir uma mais-valia, a desapropriação exige que o usuário da terra abandone sua terra de uma vez por todas. Então, enquanto um regime de produção depende de um mecanismo para garantir a apropriação duradoura do trabalho do trabalhador (Burawoy, I979; I985), um regime de desapropriação depende de um mecanismo para garantir o cercamento único da terra e o afastamento de seus donos/usuários. Visto que a exploração de trabalho confronta o explorado com exigências diferentes daquelas que a desapropriação faz ao desapropriado, sua relação com o poder subjetivo (ou "ideologia") difere de várias maneiras.

Em primeiro lugar, enquanto a expropriação de mais-valia no processo trabalhista pode ser mistificada, a expropriação de terra é sempre transparente. Enquanto um trabalhador pode não perceber diretamente que sua mais-valia está sendo extraída no processo de trabalho (pois os trabalhos "necessário" e "excedente" se confundem no salário, que aparenta representar a compensação por um dia inteiro de trabalho), nenhum fazendeiro deixa de perceber e entender a desapropriação de sua terra. A inevitável transparência da desapropriação, que resulta da intervenção direta da coerção extraeconômica, torna uma mistificação impossível. Sem o benefício da invisibilidade, o Estado precisa garantir a desapropriação por meio de formas explícitas de persuasão: sejam estas apelos normativos, concessões materiais ou a ameaça de violência.

Em segundo lugar, enquanto os marxistas ocidentais e teóricos críticos têm procurado explicar a reprodução de relações sociais de propriedade, a desapropriação requer uma teoria de poder capaz de explicar a aquiescência a transformações dramáticas das relações de propriedade sociais. A pergunta não é: por que o trabalhador continua trabalhando, reproduzindo assim a não propriedade dos meios de produção? A pergunta é: o que compele alguém a abrir mão de seus meios de produção de todo? Se fazê-lo significa uma ameaça grande e normalmente irreversível ao seu modo de vida tradicional, como o Estado consegue realizar essa desapropriação com outro meio se não a força bruta? Nesse sentido, a produção de aquiescência à desapropriação se parece mais com a tentativa de convencer as pessoas a optarem pelo socialismo-com sua disrupção inevitável de formas de propriedade e seus respectivos estilos de vida existentes - do que manter sua lealdade ao capitalismo. Enquanto o 
papel da ideologia na exploração capitalista é garantir uma reprodução social tranquila, o papel da ideologia na desapropriação é possibilitar uma mudança social traumática.

A terceira distinção segue da segunda: enquanto a reprodução de relações sociais capitalistas exige formas contínuas de submissão, a desapropriação exige uma aquiescência de prazo muito curto (mas normalmente com consequências irreversíveis). Como processo singular e discreto - o Estado precisa se apoderar apenas uma vez da terra de um fazendeiro -, a desapropriação não exige (e talvez nem seja capaz de produzir) uma dominação constante. A pergunta do ponto de vista do Estado e do capital não é: como posso criar um sujeito capitalista duradouro? A pergunta é: como consigo retirar o fazendeiro e cercar a sua terra hoje? Muitas vezes, o desapropriador não se interessa mais pelo desapropriado uma vez que conseguiu isolá-lo dos seus meios de produção. Como veremos, isso é o caso principalmente em países de trabalho de mais-valia após um crescimento intenso não baseado em trabalho.

O ponto importante, porém, é que o que motiva a desapropriação de terra é o interesse do capital na terra - e não no trabalho: uma vez apropriada a terra, a transformação de fazendeiros em sujeitos capitalistas mansos é irrelevante.

Em resumo: enquanto as teorias marxistas de ideologia alegavam tratar do problema da ideologia capitalista em geral, na verdade, limitaram-se às exigências ideológicas da exploração capitalista (ou da "reprodução expandida"). Se - como argumentei - a acumulação por desapropriação é um fenômeno significativo, contínuo e profundamente capitalista, precisamos aceitar que todas essas teorias são parciais. Parecem inadequadas - talvez até sofisticadas demais - para o problema da desapropriação.

Devemos, então, contemplar a desapropriação como um problema de consenso. A sociologia do consenso surgiu nos meados do século XX de uma preocupação com a função de organizações de grande escala no Ocidente (ver Bendix, I947; Etzioni, I96I). Apoiando-se na teoria de dominação de Weber (I978), seu representante mais proeminente definiu o consenso "como relação na qual um agente se comporta de acordo com uma diretiva sustentada pelo poder de outro, e na qual o agente subordinado se orienta pelo poder aplicado" (Etzioni, I96I: 3). Existem três formas principais de poder que podem ser usadas para gerar consenso: coerção, remuneração material e persuasão normativa. Já que a tentativa de gerar consenso por meio da coerção costuma gerar alienação, um consenso mais positivo pode ser induzido por meio de cálculos materiais ou da legitimidade normativa. A pergunta é: sob quais circunstâncias e entre quais grupos as diferentes formas de poder produzem um consenso diferentemente motivado? Enquanto Etzioni fornece uma tipologia estática de consenso (ver Burawoy, I985: 9), eu uso o termo num sentido mais dinâmico, examinando os meios historicamente específicos disponíveis a diferentes regimes de desapropriação para expulsar as pessoas de suas terras. O consenso pode ter 
sido um conceito inadequado para a submissão duradoura exigida pelo processo de trabalho (ao qual foi originalmente aplicado), mas satisfaz as exigências da desapropriação.

O conceito do consenso apresenta duas vantagens no estudo da desapropriação. Em primeiro lugar, ele não depende de um conceito de mistificação, ou seja, da produção de uma "lacuna entre experiência e realidade para todos que participam de um conjunto específico de relações sociais" (Burawoy \& Von Holdt, 20I 2: I79). Mesmo que "consenso" não signifique necessariamente um consentimento racional, ele implica, sim, uma reação explícita a uma ordem explícita, e não uma operação "automática" ou oculta de poder. Isso o torna mais apropriado para o estudo da desapropriação com sua transparência inescapável do que para seu emprego original no estudo do local de trabalho. Em segundo lugar, o consenso à desapropriação não supõe nada mais sobre as subjetividades dos indivíduos além do fato de abandonarem suas terras. Enquanto a exploração exige um consenso duradouro no ponto de produção, a desapropriação exige apenas o consenso em um único momento no ponto de cercamento. Mesmo que os indivíduos que consentem - ou não - com a desapropriação possam ter sido sujeitos a muitas formas de socialização de longo prazo, esses processos são ortogonais à desapropriação, e suas consequências para o consenso só podem ser incidentais. Mesmo que uma submissão arraigada à autoridade estatal possa ser claramente útil, a socialização capitalista no sentido de respeito pela propriedade particular só pode ter um efeito negativo sobre o consenso à desapropriação.

Apesar de dizer pouco sobre a profundidade ou a persistência de seus efeitos, o conceito do consenso permite uma variação nos três modos pelos quais os Estados tentam alcançar o consenso à desapropriação e nas razões subjetivas do consenso. A tipologia de Etzioni do consenso coercivo, normativo e remunerativo corresponde à minha análise dos meios disponíveis aos regimes de desapropriação. Mesmo que nenhum regime de desapropriação possa se apoiar na mistificação, todos eles se apoiam, em alguma medida, no emprego ou na ameaça de coerção. Esse fato destaca a distinção crítica entre desapropriação e exploração. Quando um Estado informa o fazendeiro sobre sua intenção de adquirir sua terra, o possível emprego de força estatal sempre reforça essa intenção (isso nem sempre é o caso quando o capitalista ordena que o trabalhador trabalhe). Em última análise, se o fazendeiro se recusa a abandonar sua terra, a ameaça de coerção se transforma em violência real - o "sangue e fogo" da acumulação primitiva de Marx. Evidentemente, em vista dos custos sociais e políticos do emprego de violência - principalmente em democracias eleitorais - os Estados costumam dar preferência a outros meios para efetuar a desapropriação. Os regimes de desapropriação variam no grau em que precisam apostar no uso de coerção bruta para gerar o consenso, podendo recorrer também a meios normativos e materiais. 
Os Estados quase sempre acreditam que seja necessário justificar seu uso de poder coercivo para redistribuir propriedade. Isso não vale apenas para as democracias liberais; apesar de poderem recorrer a uma coerção maior, os governos autoritários normalmente se sentem compelidos a justificar a desapropriação como algo que serve aos interesses públicos ou nacionais. Os primeiros cercamentos na Inglaterra recorreram ao conceito da "melhoria" de Locke (I952[I690]: 37) para justificar suas ações. As formas contemporâneas de desapropriação costumam recorrer à linguagem derivativa do "desenvolvimento". Um dos fatores principais no sucesso e na estabilidade de um regime de desapropriação é à medida que seus apelos ao interesse público conseguem convencer a pluralidade e os desapropriados. Isso depende fundamentalmente dos propósitos econômicos usados para justificar a desapropriação e seus beneficiários. Tudo indica, por exemplo, que os camponeses ingleses rejeitaram os argumentos morais e jurídicos usados para justificar os cercamentos (Thompson, I975), que se apoiavam naquilo que E. P. Thompson chama de "a ascendência da força" (I975: 23). No Ocidente, o consenso foi facilitado pelo fato de que os cercamentos em grande escala ocorreram antes da instituição da democracia eleitoral - ou se voltavam contra populações sem direito a voto (Banner, 2005). Mesmo que os governos muitas vezes tenham considerado necessário apelar à eficiência ou à civilização e a adequar a desapropriação às suas leis e à sua autocompreensão (Banner, 2005), a desapropriação ocorreu mais pela aplicação de força do que pela persuasão. O mesmo vale, obviamente, para a desapropriação pelas autoridades coloniais. O papel quase universal da violência nos esforços de "modernizar" as regiões rurais levou Barrington Moore a observar que "não há evidências de que a população tenha desejado uma sociedade industrial; há, porém, uma abundância de evidências de que não a desejavam. A base de todas as formas de industrialização tem sido, até agora, revoluções de cima, a obra de uma minoria inescrupulosa" (I966: 506). No entanto, em muitas nações pós-coloniais emergentes, essa minoria inescrupulosa se viu obrigada a recorrer a uma força normativa maior do que os regimes coloniais e pré-democráticos em seus projetos de "modernizar a nação". Como veremos, aquilo que chamarei de regime nehruviano de desapropriação na Índia teve um apoio ideológico forte e bastante amplo durante muitas décadas após a conquista de sua independência; o regime neoliberal, porém, é outra história.

A outra base para o consenso é o apelo aos interesses materiais dos desapropriados. Dada a natureza de soma-zero da propriedade de terra, isso não é uma tarefa fácil. Enquanto poucos incentivos foram oferecidos aos camponeses ingleses para abandonarem suas terras comunais - foram expulsos sem compensação e transformados em um proletariado destituído - a maioria das sociedades contemporâneas exige que as pessoas despojadas de sua propriedade privada recebam alguma forma de compensação. 
Às vezes, os Estados baseiam essa compensação numa avaliação do "valor de mercado" dessa propriedade (embora a determinação desse valor, na ausência de uma transação voluntária, apresente certas dificuldades) e, em décadas recentes, eles têm, por vezes, incrementado essa compensação por meio de políticas explícitas de "reassentamento e reabilitação". Isso pode incluir a garantia de um emprego na atividade econômica projetada para sua terra; às vezes, inclui terra irrigada pela represa que inundará sua terra atual. Ambas as possibilidades são historicamente raras, e veremos que o histórico de "compensações" e "reassentamentos e reabilitações" na Índia é abismal. No entanto, o desapropriador quase sempre faz algum tipo de promessa material ao desapropriado, tentando convencê-lo de que ele terá alguma participação no "desenvolvimento" que sua desapropriação torna possível. Ambos os tipos de promessas e a capacidade do Estado de cumprir suas promessas dependem fundamentalmente do tipo específico de acumulação que motiva a desapropriação. Em outras palavras: diferentes regimes de desapropriação são capazes de oferecer diferentes tipos de incentivos materiais para obter o consenso dos camponeses à sua própria desapropriação.

Assim, o consenso à desapropriação é obtido por meio de combinações historicamente específicas de poder coercivo, material e normativo. Isso significa que os regimes de desapropriação são hegemonias? No sentido de Gramsci, "hegemonia" se refere à capacidade de classes dominantes de convencerem classes subordinadas de que o domínio da classe dominante serve a interesses mais universais. Envolve "a combinação de força e consenso", sendo que este último é construído por meio de persuasão cultural e concessões materiais (Gramsci, I97I: 80, I6I, I8I; Burawoy, I979, I985; Przeworski, I985).

No entanto, o conceito da hegemonia não se alinha nem social nem temporalmente com a política da desapropriação: a hegemonia se refere a alinhamentos políticos relativamente duradouros entre classes ("blocos históricos"), enquanto a desapropriação é, em qualquer instância específica, um processo de curto prazo que ignora alinhamentos entre classes ou partidos. Quando o Estado desapropria de forma indiscriminada todos os habitantes de uma região geográfica específica, isso afeta classes agrárias múltiplas e contraditórias de diversas alianças políticas desenvolvidas em torno de outros processos sociais mais constantes. Se alguém se submete à desapropriação, isso não sinaliza necessariamente que ele a aprove, muito menos que ele apoie o programa político da fração de classe que se beneficia dela: nada disso é necessário para o consenso. E vale também o contrário: o fato de alguém se opor à desapropriação não significa que ele rejeite aquela forma de desenvolvimento e os interesses de classe que ela representa (seja o capital financeiro para zonas econômicas especiais, o capital industrial para uma usina siderúrgica ou o capital agrário para uma represa). Pode simplesmente não querer ceder sua terra para isso. Apesar de apresentar um aspecto de classes, a política de de- 
sapropriação não corresponde claramente a hegemonias estabelecidas e a suas visões de desenvolvimento. Hegemonias e desapropriação são fenômenos sociais ortogonais. O consenso representa um ponto de partida melhor como denominador mínimo comum. A princípio, os regimes de desapropriação não precisam produzir consenso, lealdade política duradoura ou transformações nas subjetividades dos desapropriados; precisam apenas tirá-los de suas terras.

\section{DESAPROPRIAÇÃO E ACUMULAÇÃo}

A acumulação só pode ocorrer após a expulsão do desapropriado de sua terra, realizando (e iluminando) os interesses de classe que motivaram a desapropriação e desencadeando mudanças socioeconômicas que afetam os desapropriados e a sociedade como um todo. A fim de entender a acumulação por desapropriação é, portanto, necessário analisar empiricamente o que realmente acontece na terra desapropriada, os tipos de mudanças econômicas que isso provoca e quem se beneficia dessas mudanças. Enquanto a maioria dos marxistas (por vezes, até Harvey) e os teóricos da modernização alegam que a desapropriação (ou "acumulação primitiva") foi historicamente progressiva, os efeitos da desapropriação variam muito entre os diferentes regimes de desapropriação. Ser desapropriado para um projeto florestal colonial é bem diferente de ser desapropriado para uma represa do setor público, que também é bem diferente de ser desapropriado para uma zona econômica especial ou um projeto imobiliário da era neoliberal. Esse tipo de acumulação precisa sempre ser medida em relação à "desacumulação" da produção existente na terra que a torna possível. A contribuição de diferentes formas de acumulação por desapropriação para uma transformação ampla da base produtiva de uma sociedade e uma distribuição ampla de seus benefícios - o que poderíamos chamar de desenvolvimento - é, portanto, de uma grandeza bastante variável. As diferentes formas de "desenvolvimento" possibilitadas pela desapropriação em diferentes regimes é, sobretudo, de importância central para compreender a medida de resistência à desapropriação em diferentes contextos históricos.

A desapropriação de produtores diretos não é, portanto, uma fase necessária do desenvolvimento econômico: não é nem fase nem necessariamente geradora de desenvolvimento. O conceito de regimes de desapropriação nos convida a contemplar a desapropriação como uma forma contínua de redistribuição coerciva que serve a diferentes propósitos e interesses de classe em diferentes períodos, mas cuja relação com o progresso econômico é sempre uma pergunta aberta.

\section{CONCLUSÃO}

Há um reconhecimento crescente de que a maneira como as sociedades expropriam o trabalho não é o único fato relevante na tentativa de compreender 
estruturas sociopolíticas e de demarcar seus eixos de conflito de classes. A maneira como as sociedades expropriam terra e recursos naturais e a maneira como produzem espaço para qualquer configuração político-econômica são igualmente centrais; na verdade, contêm um potencial político explosivo em muitas partes do Hemisfério Sul atual. Incentivados por uma proliferação de movimentos e levantes contra várias formas de desapropriação e cercamento, os estudiosos estão agora se perguntando se a "acumulação primitiva", identificada por Marx com a aurora da era capitalista, não seria, na verdade, um de seus aspectos contínuos e constitutivos (Perelman, 2000; De Angelis, 200I; Hart, 2002; RETORT, 2005; Arrighi, 2007; De Angelis, 2007; Sanyal, 2007; Sassen, 2010). A formulação de Harvey $(2003,2005)$ da "acumulação por desapropriação" fornece uma etiqueta útil e menos anacrônica para diversas formas de desapropriações contemporâneas de terra que resultam de capitalismos maduros (em vez de gerar uma transição para estes). No entanto, com a aceleração sem precedente da escala de desapropriação e da pesquisa sobre esta, surge também a necessidade de trazer clareza para a confusão teórica em torno desses termos e de desenvolver uma estrutura mais conducente à pesquisa comparativa. Sugeri que uma teoria dos regimes de desapropriação poderia fornecer um ponto de partida melhor para uma sociologia da desapropriação.

O conceito de regimes de desapropriação pretende responder às teorias economicistas de desapropriação destacando a natureza política irreduzível da desapropriação como processo. Sugere que o ponto de partida para compreender as desapropriações não é sua função no capitalismo, mas os meios distintivos de produzir várias formas de perda de propriedade em contextos diferentes. Incentiva um distanciamento das abstrações globais referentes à "lógica do capital" em direção ao estudo concreto de relações específicas de desapropriação entre pessoas em contextos diferentes. Em última análise, a desapropriação é um processo por meio do qual os detentores de meios de coerção obrigam os detentores de meios de produção ou subsistência (comunal ou privada) a cedê-los a terceiros. O estudo da desapropriação deve começar aqui, no ponto do cercamento. Partindo daqui, é possível examinar os propósitos econômicos e interesses de classe variáveis que motivam a desapropriação em diferentes momentos e lugares; como eles determinam a capacidade do Estado de produzir consenso à desapropriação; o tipo de acumulação que isso facilita; e as consequências de tudo isso para os desapropriados. Visto que a desapropriação é uma relação política de redistribuição fundamentada em diferentes configurações de classes e executada por Estados com seus meios específicos de gerar consenso (incluindo os idiomas específicos de justificação), devemos esperar uma heterogeneidade incrível. A inseparabilidade da política da acumulação garante essa heterogeneidade. Então, ao mesmo tempo em que começa com os aspectos genéricos que definem a desapropriação como processo social em qualquer contexto, os regimes de desapropriação preservam a flexibilidade para 
captar sua heterogeneidade ao longo do tempo em diferentes espaços. A comparação de regimes de desapropriação é mais satisfatória do ponto de vista analítico do que a redução de todas as formas de desapropriação à lógica global do capital, e é também mais motivador em termos políticos; pode ajudar a gerar previsões sobre a fraqueza ou durabilidade relativa de regimes diferentes e a identificar os pontos em que a política de desapropriação pode vir a interromper a "acumulação por desapropriação".

Recebido em 06/oI/20I4 | Aprovado em 20/03/20I4

Michael Levien é Ph.D em Sociologia pela Universidade da Califórnia, Berkeley, e professor do Departamento de Sociologia na Johns Hopkins University, Baltimore. Suas áreas de interesse são sociologia, sociologia política, economia política agrária e teoria sociológica, com foco na Índia. É autor de "The politics of dispossession: Theorizing India's 'land wars'” (2013) e "Regimes of dispossession: From steel towns to Special Economic Zones" (2013). 


\section{REFERÊNCIAS BIBLIOGRÁFICAS}

Adnan, Shapan. (1985). Classical and contemporary approaches to agrarian capitalism. Economic and Political Weekly, 20/30, p. 53-64.

Anderson, Perry. (1974). Lineages of the Absolutist State. Londres: New Left Books.

Arrighi, Giovanni. (2007). Adam Smith in Beijing: Lineages of the twenty-first century. Londres: Verso.

Arrighi, Giovanni. (1994). The long twentieth century. Londres: Verso.

Arrighi, Giovanni. (1978). The geometry of imperialism: The limits of Hobson's paradigm. Londres: New Left Books.

Arrighi, Giovanni; Aschoff, Nicole \& Scully, Ben. (2010). Accumulation by dispossession and its limits: The Southern Africa paradigm revisited. Studies in Comparative International Development, 45, p. 4IO-438.

Arrighi, Giovanni \& Piselli, Fortunata. (1987). Capitalist development in hostile environments: Feuds, class struggles, and migrations in a peripheral region of Southern Italy. Review, Io/4, p. 649-75I.

Balibar, Etienne. (I979). Elements for a theory of transition. In: Althusser, Louis \& Balibar, Etienne (orgs.). Reading Capital. Londres: Verso, p. 273-308.

Banner, Stuart. (2005). How the Indians lost their land: Law and power on the frontier. Cambridge: The Belknap Press of Harvard University Press.

Baviskar, Amita. (I995). In the belly of the river: Tribal conflicts over development in the Narmada Valley. Oxford: Oxford University Press.

Bhaduri, Amit. (1983). The economic structure of backward agriculture. Londres: Academic Press.

Byres, Terence J. (I99I). The agrarian question and differing forms of capitalist agrarian transition: An essay with reference to Asia. In: Breman, Jan \& Mundle, Sudipto (orgs.). Rural transformation in Asia. Nova Deli: Oxford University Press, pp. 3-76.

Brenner, Robert. (2006). What is, and what is not, imperialism? Historical Materialism, I4/4, p. 79-105. 
Brenner, Robert. (200I). The low countries in the transition to capitalism. Journal of Agrarian Change, I/2, p. I69-24I.

Brenner, Robert. (I977). The origins of capitalist development: A critique of neo-Smithian marxism. New Left Review, I04, p. 25-92.

Brenner, Robert. (1976). Agrarian class structure and economic development in preindustrial Europe. Past and Present, 70, p. 30-75.

Brewer, Anthony. (1990). Marxist theories of imperialism. Londres: Routledge.

Bukharin, Nikolai. (I973[I9I7]). Imperialism and world economy. Nova York: Monthly Review Press.

Burawoy, Michael. (1985). The politics of production: Factory regimes under capitalism and socialism. Londres: Verso.

Burawoy, Michael. (1979). Manufacturing consent: Changes in the labor process under monopoly capitalism. Chicago: University of Chicago Press.

Burawoy, Michael \& Holdt, Karl von. (20I2). Conversations with Bourdieu: The Johannesburg moment. Joanesburgo: Wits University Press.

Cernea, Michael. (I999). The economics of involuntary resettlement: Questions and challenges. Washington, D.C.: World Bank.

Coronil, Fernando. (1997). The magical state: Nature, money, and modernity in Venezuela. Chicago: The University of Chicago Press.

De Angelis, Massimo. (2007). The beginning of history: Value struggles and global capital. Londres: Pluto Press.

De Angelis, Massimo. (200I). Marx and primitive accumulation: The continuous character of capital's enclosures. The Commoner, 2, p. I-22.

Dobb, Maurice. (1947). Studies in the development of capitalism. Nova York: International Publishers.

Etzioni, Amitai. (196I). A comparative analysis of complex organizations. Londres: The Free Press.

Fernandes, Walter \& Paranjpye, Vijay (orgs.). (I997). Rehabilitation policy and law in India: A right to livelihood. Nova Deli: Indian Social Institute. 
Fernandes, Walter \& Thukral, Enakshi Ganguly (orgs.). (I989). Development, displacement, and rehabilitation: Issues for a national debate. Nova Deli: Indian Social Institute.

Frank, Andre Gunder. (I979). Dependent accumulation and underdevelopment. Nova York: Monthly Review Press.

Glassman, Jim. (2006). Primitive accumulation, accumulation by dispossession, accumulation by extra-economic means. Progress in Human Geography, 30/5, p. 608-625.

Gramsci, Antonio. (I97I). Prison notebooks. Nova York: International Publishers.

Guha, Ramachandra. (I989). The unquiet woods: Ecological change and peasant resistance in the Himalaya. Nova Deli: Oxford University Press.

Hall, Derek. (20I2). Rethinking primitive accumulation: Theoretical tensions and rural Southeast Asian complexities. Antipode, 44/4, p. I I88-2008.

Hart, Gillian. (2002). Disabling globalization: Places of power in post-apartheid South Africa. Berkeley: University of California Press.

Harvey, David. (2006). Comment on commentaries. Historical Materialism, I4/4, p. I57-I66.

Harvey, David. (2003). The new imperialism. Oxford: Oxford University Press.

Heller, Patrick. (I999). The labor of development: Workers and the transformation of capitalism in Kerala, India. Ithaca: Cornell University Press.

Hildferding, Rudolf. (I98I[I9I0]). Finance capital: A study of the latest phase of capitalist development. Londres: Routledge.

Hobson, John A. (1965). Imperialism, a study. Ann Arbor: University of Michigan Press.

Ka, Chih-ming \& Selden, Mark. (I986). Original accumulation, equity and late industrialization: the cases of socialist China and capitalist Taiwan. World Development, I4/Io, p. I293-I3Iо.

Kautsky, Karl. (I 988). The agrarian question. Londres: Zwan Publications.

Lefebvre, Henri. (I99I). The production of space. Oxford: Blackwell Publishers. 
Lenin, Vladimir I. (1967). The development of capitalism in Russia. Moscou: Progress Publishers.

Lenin, Vladimir I. (I939[I9I7]). Imperialism: The highest stage of capitalism. Nova York: International Publishers.

Levien, Michael. (20I2). The land question: Special Economic Zones and the political economy of dispossession in India. Journal of Peasant Studies, 39/3-4, p. 933-969.

Levien, Michael. (20I I). Special Economic Zones and accumulation by dispossession in India, Journal of Agrarian Change, I I/4, p. 454-483.

Linebaugh, Peter. (2008). The Magna Carta Manifesto: Liberties and commons for all. Berkeley: University of California Press. Locke, John. (I952[1690]). The second treatise of government. Indianapolis: The Library of Liberal Arts.

Luxemburgo, Rosa. (2003[I9I3]). The accumulation of capital. Londres: Routledge.

Marx, Karl. (I977). O capital. Volume I. Nova York: Vintage.

Marx, Karl. (1973). Grundrisse. Londres: Penguin.

McMichael, Philip. (2013). Land grabbing as security mercantilism in international relations. Globalizations, Io/I, p. 47-64. McMichael, Philip. (20I2). The land grab and corporate food regime restructuring. Journal of Peasant Studies, 39/3-4, p. 68I-70I.

McMichael, Philip. (I996). Development and social change: A global perspective. Thousand Oaks: Pine Forge Press.

Moore, Donald S. (2005). Suffering for territory: Race, place, and power in Zimbabwe. Durham: Duke University Press.

Moore, Barrington. (1966). Social origins of dictatorship and democracy: Lord and peasant in the making of the modern world. Boston: Beacon Press.

Parasuraman, S. (I999). The development dilemma: Displacement in India. Nova York: St. Martin's Press.

Peet, Richard \& Watts, Michael (orgs.). (2004 [1996]). Liberation ecologies: Environment, development, social movements. Londres: Routledge.

Peluso, Nancy Lee \& Watts, Michael (orgs.). (200I). Violent environments. Ithaca: Cornell University Press. 
Perelman, Michael. (2000). The invention of capitalism: Classical political economy and the secret history of primitive accumulation. Durham: Duke University Press.

Preobrazhensky, Evgeny. (1965). The new economics. Oxford: Clarendon Press.

Przeworski, Adam. (1985). Capitalism and social democracy. Cambridge: Cambridge University Press.

Roseberry, William. (1994). Anthropologies and histories: Essays in culture, history, and political economy. New Brunswick: Rutgers University Press.

RETORT. (2005). Afflicted powers: Capital and spectacle in a new age of war. Londres: Verso.

Reynolds, Susan. (2010). Before eminent domain: Toward a history of expropriation of land for the common good. Chapel Hill: The University of North Carolina Press.

Sanyal, Kalyan. (2007). Rethinking capitalist development: Primitive accumulation, governmentality, and post-colonial capitalism. Nova Deli: Routledge.

Sassen, Saskia. (2013). Land grabs today: Feeding the disassembling of national territory. Globalizations, Io/I, p. 25-46. Sassen, Saskia. (20I0). A savage sorting of winners and losers: Contemporary versions of primitive accumulation. Globalizations, 7/I, p. 23-50.

Sundar, Nandini. (2007). Subalterns and sovereigns: An anthropological history of Bastar, I 954-2006. Nova Deli: Oxford University Press.

Thompson, E. P. (1975). Whigs and hunters: The origin of the Black Act. Nova York: Pantheon.

Thukral, Enakshi Ganguly (org.). (1992). Big dams, displaced people. Nova Deli: Sage Publications.

Wallerstein, Immanuel. (201 I [1989]). The modern world system III: The second era of great expansion of the capitalist world economy, I730s-I840s. Berkeley: University of California Press.

Wallerstein, Immanuel. (1974). The rise and demise of the world capitalist system: Concepts for comparative analysis. Comparative Studies in Society and History, I6/4, p. 387-4I5.

Warren, Bill. (I980). Imperialism: Pioneer of capitalism. Londres: New Left Books. 
Watts, Michael. (2004a [1996]). Violent environments: Petroleum conflict and the political ecology of rule in the Niger Delta, Nigeria. In: Peet, Richard \& Watts, Michael (orgs.). Liberation ecologies: Environment, development, social movements. Londres: Routledge, p. 273-298.

Watts, Michael. (2004b). Antinomies of community: Some thoughts on geography, resources and empire. Transactions of the Institute of British Geographers, 29/2, p. I95-216.

Weber, Max. (1978). The types of legitimate domination. In: Roth, Guenther \& Wittich, Claus (orgs.). Economy and Society. Berkeley: University of California Press, p. 21 2-30I.

Wood, Ellen Meiksins. (2002). The origin of capitalism: A longer view. Londres: Verso.

Zoomers, Anneleis. (2010). Globalisation and the foreignisation of space: Seven processes driving the current global land grab. The Journal of Peasant Studies, 37/2, p. 429-447. 
Palavras-chave

Teoria sociológica;

Regimes de

desapropriação;

Acumulação de capital;

Marxismo.

\section{DA ACUMULAÇÃO PRIMITIVA AOS REGIMES DE DESAPROPRIAÇÃO}

\section{Resumo}

Este trabalho defende uma teoria da relação entre desapropriação de terras e capitalismo, que chamo de "regimes de desapropriação". Essa teoria fornece um meio de entender as formas sociais e históricas específicas assumidas pela desapropriação, suas mudanças ao longo do tempo e como essas mudanças afetam o "desenvolvimento" econômico e a política. "Regimes de desapropriação" preenche uma lacuna na sociologia do desenvolvimento e reconstrói a teoria de Marx da "acumulação primitiva" e a teoria da "acumulação por desapropriação", de Harvey, com a finalidade de providenciar um quadro teórico mais adequado para compreender as desapropriações de terra no passado e no presente.

\section{FROM PRIMITIVE ACCUMULATION TO REGIMES OF DISPOSSESSION}

\section{Abstract}

Keywords

Sociological theory; The present work advances a theory of the relationship between land dispossession and capitalism, a theory I call Regimes of dispossession; "regimes of dispossession". This theory provides a way of understanding the socially and historically specific forms

Capital accumulation;

Marxism. dispossession takes, how it changes over time, and how these changes effect economic "development" and politics. "Regimes of dispossession" fills an absence in development sociology, and reconstructs Marx's theory of "primitive accumulation" and Harvey's "accumulation by dispossession" to provide a more adequate framework for understand land dispossessions, past and present. 